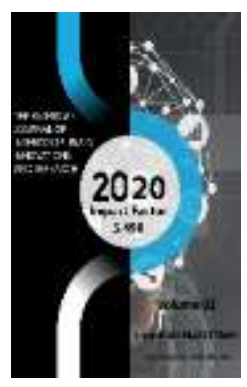

\title{
The Craftsmanship Of The Emirate Of Bukhara At The Second Half Of The XIX Century - The Beginning Of The XX Century
}

Ochildiev Fayzulla

Associate Professor, Candidate Of Historical Sciences, Department Of Archaeology Of Uzbekistan, National University Of Uzbekistan

Journal Website: http://usajournalshub.c om/index,php/tajiir

Copyright: Original content from this work may be used under the terms of the creative commons attributes 4.0 licence.

\section{ABSTRACT}

This article describes the development of handicrafts in the second half of the XIX century and the beginning of the XX century in the Emirate of Bukhara. In the Emirate of Bukhara from ancient times developed weaving, embroidery, tanning, carpet weaving, pottery, blacksmithing, coppersmithing, carving, jewelry, painting and other crafts.

\section{KEYWORDS}

Weaving, embroidery, tanning, carpet weaving, pottery, blacksmithing, coppersmithing, carving, jewelry.

\section{INTRODUCTION}

The people of the Bukhara Emirate have long been engaged in handicrafts. Depending on the level of dealing with the craftsmanship, the following can be specified in the emirate:
1. The specialization of handicrafts was strong in urban and densely populated villages. 
2. In the upper and middle reaches of the rivers, household handicrafts are well established.

3. In mountainous areas, pre-steppe and wide steppe areas, the population has developed forms of housing, that is production for themselves.

From ancient times in the Emirate of Bukhara there were favorable conditions for the development of several types of economy, in particular, agriculture, animal husbandry and handicrafts. The sources of raw materials needed for the development of handicrafts in the emirate are provided by agriculture, livestock and mineral resources. In the Emirate of Bukhara from ancient times developed weaving, embroidery, tanning, carpet weaving, pottery, blacksmithing, coppersmithing, carving, jewelry, painting and other crafts.

\section{THE MAIN RESULTS AND FINDINGS}

In Central Asia, including the Emirate of Bukhara, cotton, wool, silk and hemp yarns have long been woven at home and leather garments have been made at home. The raw materials needed for textiles, namely cotton, silk, hemp, wool and leather, were grown mainly from the emirate itself. One of the necessary raw materials in textiles is cotton, and in the early XIX-XX centuries in the Emirate of Bukhara, a local variety of cotton was planted.

As soon as the cotton crop was harvested, each household separated the cotton it needed from the seeds and prepared it for weaving fabrics and other handicrafts. In home conditions, cotton was separated from the seeds by spinning and preparing before making the fabric. One weaver was able to separate about two pounds of cotton from the seeds during the week. In many households, during the winter, the whole family manually separates the cotton from the seeds and prepares it for spinning. The spun yarn was spun, in some places the people cleaned and sold the cotton in the markets, and in some places it was spun into yarn and then sold in the markets.

S. Mazov notes that at the end of the 19th century, more than 100,000 handicrafts were woven in the Bukhara Emirate. O.A. Sukhareva noted that masters were engaged in weaving in more than 12,000 workshops in and around Bukhara. There are 9 large weaving workshops in Bukhara, each of which has 50-60 looms.

One of the most common cotton fabrics in the Emirate of Bukhara is "karbos", which is gray, and its production continues to this day. This fabric is divided into several types depending on the thickness and color. It is warm in winter and cool in summer. This fabric was produced by both urban and rural residents not only for their own needs but also for sale.

Olacha fabric has also been widely produced in the Emirate of Bukhara since ancient times. The best variety of Olacha is called zibak. The road is woven in Bukhara, Gissar, Sariosiyo, Denau, Karshi, Shakhrisabz, Kitab and other cities. The production of textiles is a complex process. Each weaver-craftsman specializes in the production of only one type of fabric. Accordingly, they have different names: velvetvelvet weavers, silk weavers - silkworms, futa weavers - futabaf, chit weavers - chitgar, olacha weavers - olachabof and so on. Textiles produced in Central Asia, including the Emirate of Bukhara, were of a commodity nature and were also used in part as a medium of 
exchange in the Middle Ages. By the second half of the nineteenth century, silkworm breeding and silk weaving in Central Asia had reached its peak of development. During this period, silk fabrics and garments produced by the local population not only competed with Russian factory goods, but were also popular and in demand in European markets. The handicraft-based textile craft has developed not only through ancient traditions, but also through the skill of master craftsmen over time.

The fabrics are woven in craft associations and artisan homes. There are mainly two types of textile production - for domestic needs and custom-made products for the market at home. Merchants were mainly engaged in the sale of finished textiles. By the second half of the 19th century, sewing in the emirate was much more developed, and clothes were sewn for centuries with a certain taste, taking into account age, gender, height.

In the Bukhara Emirate, embroidery was developed on the basis of silk. It is one of the most developed handicrafts in Bukhara emirate. Embroidery, which has been passed down from generation to generation for centuries, has demonstrated the creative abilities of women, their dreams, hopes, love for nature and beauty. The range of embroidery items includes: "suzana, zardevol, joynomoz, bogjoma, oynakhalta, zardevor, naprach, sheets, palak, doppi" and others. Leather handicrafts are developed in the emirate. Craftsmen have produced various household products such as telpaks, boots , makhsi , mokki, sandals, stockings, popush.

Residents of the Surkhandarya oasis, which is part of the Bukhara Emirate, have also been engaged in handicrafts. The main occupation of the urban and rural population was the preparation of food and handicrafts for their daily needs. Crafts such as cotton, silk, leather processing, metal and ceramics, saddles, footwear, tanning, fabric dyeing and floral printing, cast iron and iron processing, coppersmithing, jewelry and milling are well developed.

By the second half of the XIX-beginning of the $X X$ century, Sherabad, Denau, Termez, Boysun, Yurchi and other cities became the centers of handicrafts of the emirate. In these cities all branches of handicrafts were well developed. In the production of handicrafts, each city was distinguished by its own products. For example, the city of Bukhara was famous for its fabrics woven from cotton and other products, gold embroidery and jewelry, and the city of Denau was famous for its fabrics woven from silk.

At the end of the 19th century, as a result of the expansion and development of cotton fields throughout the emirate, the demand for labor tools in agriculture increased. For this reason, many blacksmithing and casting workshops were built in Sariosiya, Boysun, Denau and other cities, and the population's demand for agricultural weapons was regularly met. Gradually, several towns and villages became major centers for the production of handicrafts.

In the cities of Boysun, Termez, Sherabad, Sariosiya, Denau, Yurchi, a lot of cotton and silk fabrics are made. The quality of the woolen cloth woven from cotton was quite mature. Therefore, it was taken to Samarkand, Tashkent, Bukhara, Afghanistan and India. 
Carpet weaving was of special importance in oasis handicrafts. The carpet was mostly woven by women. In the field of carpet weaving, it is worth mentioning the cities of Termez and Sherabad. According to $\mathrm{K}$. Khakimova, the carpets woven here are popular not only in Central Asia, but also in Russia and the whole of Western Europe, and are sold at high prices. Several types of carpets were exhibited in Paris and received high praise. Quality carpets are mostly woven in Sherabad principality. Separate well-woven carpets were sold by traders to markets in Karshi, Karki, and Shakhrisabz, and even across the Amu Darya to Afghanistan and India.

In addition to Uzbeks, Turkmen and Afghans were also famous for carpet weaving in the Sherabad principality. In addition to carpets, Turkmens also weave koshma (a type of chakman), and in autumn up to 500 koshma are sold on Sundays. In Sariosiyo, Yurchi, and Denau, in addition to weaving cotton and wool, handicrafts such as woodworking, weaving, shoemaking, blacksmithing, coppersmithing, jewelry, pottery, milling, dyeing, weaving, knife-making, and others were well developed. In Sariosia, more blacksmithing of handicrafts is well developed. There were many foundry workshops, where craftsmen regularly provided the surrounding population with tools and hammer teeth used in agriculture.

Crafts, one of the main occupations of the population, is well developed in the Boysun principality. Small types of handicrafts such as cotton and wool weaving, blacksmithing, coppersmithing, jewelry, pottery, shoemaking, leather, confectionery, milling, hairdressing, dyeing, carving, embroidery and embroidery are well developed here.
Blacksmiths, in turn, are divided into separate specialties: blacksmiths-steelworkers, plumbers-household workers. The blacksmiths were engaged in making things from iron. They are divided into degreasers - cast irons, coppersmiths and others.

At the beginning of the XIX-XX centuries, handicrafts were developed in Karshi, Shakhrisabz, Kitab, Guzar, Yakkabog and Chirakchi Bukhara emirates, which were among the largest trade cities. In the Kashkadarya oasis, textiles, embroidery, carpet weaving, pottery, coppersmithing, jewelry, blacksmithing, carpentry, tanning and other types of handicrafts have been developed since ancient times.

Among the fabrics made in the cities of the oasis, the production of gray was of particular importance. The gray fabric is made of cotton yarn and is distinguished by its firmness and warmth. Gray fabric is widely produced in Shahrisabz and Karshi. According to Mahmud ibn Wali, a large quantity of sarbas-boz (unpainted white cloth) was made in Shahrisabz. Recent sources also acknowledge that guzars specializing in making ice have survived in Shakhrisabz. Most of the population made clothes from Boz, turbans, tablecloths and so on. After the gray was painted in different colors, a new fabric - chit was created by pressing a pattern on it. It is used to make women's clothing and bedding.

Among the fabrics made in the cities of the oasis, the fabric called olacha was the most popular. Olacha is a simple fabric woven from cotton and silk, and its varieties are woven such as zibak, silky olacha, farangi. Farangi olacha is woven mainly from yarn imported from Russia. Olacha is also produced in large quantities in 
Shakhrisabz, but the main center for making olacha is Karshi. N.Khanykov notes that the majority of the population of Karshi is engaged in the preparation of oats. In the early twentieth century, Karshi masters were famous for making olacha. The masters who made olacha lived in the city's Upper Zagza guzar. Gowns, coats and other outerwear are mainly made of this fabric.

In the cities of the oasis, especially in Shakhrisabz and Karshi, the production of silk fabrics is also highly developed. In the cities of the oasis lived ready-made clothes, especially hats. Among the hats, Shahrisabz skullcaps were the most popular. Karshi's Makhsumabad neighborhood was the leader in weaving adras. According to L.Sobolev, during the reign of Amir Shahmurad, masters of adras weaving, brought from Merv, greatly assisted the artisans of Bukhara, Samarkand, Urgut and Karshi in weaving high-quality adras. In Eastern Bukhara, artisans were also engaged in handicrafts such as oil weaving, objuvoz, milling, tannery, shoemaking, blacksmithing, coppersmithing, jewelry, as well as weaving, weaving wool and cotton fabrics, yarn, carpets, baskets. Craftsmen's products are mostly made at home. The princes were distinguished by their products. Darvoz specializes in the production of tools used in agriculture, with the production of Qabodiyon silk yarn, Kulob and Baljuon leather products, Gissar silk fabric and cold steel. Silk fabric is mainly produced in Dushanbe, Karatag, Sarasiyo and partly in Qabodiyon principality. Karatag was famous for the production of cold steel. The handicrafts produced here were used by the entire population of Central Asia. Matveev, a member of the General Staff, said that the knives, daggers, swords and household items made in Karatag were very well made and tastefully made, and that every craft item attracted people. The principalities of Baljuon and Kulob were also famous for pottery, cotton weaving, and partly silk production. The principality of Kulob is famous in the Bukhara Emirate for the production of leather products. Sources say that there are many tanneries in Kulob. The principality of Qorategin is more adapted to the production of cotton woven fabrics, utensils for household use by the villagers, and various baskets, chakmon (koshma), sacks, and hot socks (chulok). General Staff Captain Vasilevv writes that the quality of the shawls and socks produced in Qorategin is very durable and always keeps a person warm from the cold.

Various types of handicrafts were developed in the Darvaz principality, where mainly iron handicrafts were made, such as sickles, hoes, hammers, hammers, axes, plowshares, horseshoes, knives, scissors and other items. Demand for iron handicrafts is high in the Darvaz principality, which is sold in all regions of the Bukhara Emirate.

\section{CONCLUSION}

In the early 19th century, handicrafts produced in the oasis partially met the needs of the population, but the standard of living of artisans was much lower. Local authorities have forced artisans to make various payments and obligations in addition to the taxes imposed in the emirate. Also, the country has not provided material and moral support to artisans, their achievements have not been encouraged.

By the beginning of the twentieth century, as a result of the influx of modern industrial 
products from Russia and other countries, processed in workshops and factories and of better quality and durability than local handicrafts, products made by local artisans began to fail in the markets.

\section{REFERENCES}

1. Karmysheva B.X. O torgovle v vostochnyx bekstvax Buxarskogo xanstva $v$ nachale $X X \quad v . \quad v$ svyazi $s$ xozyaystvennoy spetsializatsiey // Tovarno-denejnye otnosheniya na Blijnem i Srednem Vostoke v эрохu srednevekovya. - M .: Nauka, 1979. - C. 117.

2. Xanykov N. Description Buxarskago xanstva. St. Petersburg 1843.- p. 112

3. Hamidova M.S. History of handicrafts of Kashkadarya oasis (XIX-early XX centuries). - Tashkent: A.Navoiy, 2009. 42. p.

4. Mazov S.I. Vastochnaya Bukhara, Badakhshan and Northern Afghanistan. Turkestanskiy sbornik. T. 404.s.5-26

5. Sukhareva O.A. $\mathrm{K}$ istorii gorodov Buxarskogo xanstva. Tashkent 1958. S.91

6. Tukhtametov T.G. Russko Buxarskie otnasheniya v kontse XIX - nachale XX v T.1966.S-64

7. A'zamova G.A. Crafts and trade in the cities of Central Asia in the late Middle Ages.-Tashkent.2000.-19. B.

8. Hamidova M.S. History of handicrafts of Kashkadarya oasis (XIX-early XX centuries). - Tashkent: A.Navoiy, 2009. 46. p.

9. Petrovskiy N.F. O shelkovodstve i shelkomotanii v Sredney Azii // Otchyot Ministerstvu finansov agenta $v$ Turkestanskom general-gubernatorstve.M. 1873 . C. 106.
10. Palen K.K. Report on the revision of the Turkestan region. Ch.2. Spb.1909. S.172.

11. Kholikulov, A. B. (2019). Bukhara emirate's farming in the XIX-XX centuries (in the case of Kashkadarya oasis stables). ISJ Theoretical \& Applied Science, 04 (72), 546-549.

12. Kholikulov, A History Of Handicrafts Of Kashkadarya Oasis In The XIX-Early XX Centuries. (2020) The American Journal of Social Science and Education Innovations, 2 (11), 30-35.

13. Omonov, Q., \& Karimov, N. (2020). Importance of Ancestoral Heritage. The American Journal of Social Science and Education Innovations, 2 (09), 196-202.

14. Rasuljanovna, I. N., \& Rakhmonqulovich, K. N. (2020). Trade Relations Between Ancient Bacteria And China On The II-I BC. The American Journal of Social Science and Education Innovations, 2 (07), 47-51. 